\title{
Forty Years of Development: Library Services at The College of The Bahamas
}

\author{
Berthamae L. Walker \\ College Librarian ${ }^{1}$ \\ Virginia C. Ballance \\ Nursing and Health Sciences Librarian
}

\begin{abstract}
From its establishment in 1974, administrators of the College of The Bahamas have taken the provision of library services seriously, realizing that any tertiary-level institution requires a strong library collection to assure its credibility as an academic institution. The library system of The College of The Bahamas consists of three libraries: the Harry C. Moore Library and Information Centre on the Oakes Field Campus, the Hilda Bowen Library on the Grosvenor Close Campus and the Northern Campus Library on the Freeport, Grand Bahama Campus as well as a small resource centre at the facility on Exuma. These libraries house collections of materials - books, journals, audio-visual resources and microfilm, as well as provide access to collections of electronic resources needed to support academic programs and research at the College. The Harry C. Moore Library and Information Centre also houses the Bahamian Special Collection, the College Archives as well as several special exhibition spaces.
\end{abstract}

\section{INTRODUCTION}

Soon after the establishment of the College of The Bahamas in 1974, one of the most important tasks it faced was to establish a library for the institution. The COB library collection was formed by amalgamating existing collections from the two Bahamas Teachers' Colleges (one located on New Providence Island and the other located on San Salvador Island) for the Oakes Field Campus library. A collection of materials at the C. R. Walker Technical College was renamed the Soldier Road Library and was destined for the College once the facility had the space to accommodate it. In 1984 following an expansion of the library space, the Soldier Road Library and the Ministry of Education's Moss Road Library were merged with the Oakes Field Library (Rolle, 1985, p. 53).

The library was of central importance in the academic enterprise because the Librarian (as the head or chief of the library was called, in British style) reported directly to the College's Principal (Ballance \& Bain, 2000). A strong library collection was seen as integral to the success of the new College and the small library expanded and doubled in size in the

\footnotetext{
${ }^{1}$ Berthamae. L. Walker, College Librarian, Libraries and Instructional Media Services and Virginia C. Ballance, Nursing and Health Sciences Librarian, The College of The Bahamas, P.O. Box N-4912, Nassau, Bahamas E-mail: berthamae.walker@cob.edu.bs

APA reference: Walker, B. L., \& Ballance, V. C. (2014). Forty years of development: Library services at the College of The Bahamas. The International Journal of Bahamian Studies, 20(2), III 41-47. https:// doi.org/ 10.15362/ijbs.v20i2.232
}

(c) B.L. Walker \& V.C. Ballance, 2014. Journal compilation (CThe International Journal of Bahamian Studies, 2014 
first years of the College's existence. Over the 40 years of the College's development, the library has grown from one small library on the Oakes Field Campus to become known in 1995 as Libraries and Instructional Media Services (LIMS), administering a network of three libraries and one resource centre in the archipelago.

\section{Chief Librarians}

The first professional librarian appointed at the new College of The Bahamas was Paul Boultbee, who served as Acting Head (19751976) and Head Librarian (1978-1981). Succeeding Head Librarians were Ruth A. Manson (1976-1977) and Graham Chan (1977-1978). During his six-year tenure at the College Boultbee established the Bahamian Special Collection and implemented a library technician training programme (P. Boultbee, personal communication, July 2014). His bibliographies on The Bahamas, which are important contributions to Bahamian scholarship, were published by the College of The Bahamas (1981) and Clio Press (1989).

Vanrea Thomas-Rolle, the first Bahamian professional librarian at the College was appointed Librarian in 1981 when she returned from study leave and served until 1990. She oversaw an expansion of library services and facility. Under her tenure and with the support of Dr. Keva Bethel as Principal, the library increased its holdings through the acquisition of an extensive collection of journals on microform.

After Thomas-Rolle left COB, Willamae Johnson, who had been with the College since 1982, became Director of Libraries and Instructional Media Services (and later, College Librarian) until her retirement in 2012. Berthamae Walker became the College Librarian in January of 2013. Dr. Walker has been employed with COB since 1987 and has worked in all functional areas of the library: Circulation, General reference, Acquisitions,
Acting Law Librarian, and Special Collections. Having been Deputy Librarian for many years, she was a natural fit for the position of College Librarian.

\section{Libraries}

Today the College of The Bahamas library system includes three libraries: the Harry C. Moore Library and Information Centre at the Oakes Field Campus; the Hilda Bowen Library, a health sciences library at the Grosvenor Close Campus in downtown Nassau; the Northern Bahamas Campus Library in Freeport, Grand Bahama and a small resource centre at the College's facility in Georgetown, Exuma.

Since the founding of COB, there had been a call for a purpose-built university library. In 1984 with funds granted by the World Bank, the Oakes Field Campus library was renovated to double its original size to accommodate its growing collections in print and microfilm as well as to provide much needed space for technical and reader services. Despite the renovation, the Library's 1984 Annual Report made the case that if $\mathrm{COB}$ was to become a bachelor degree-granting institution, it would need much better library resources and a larger facility.

\section{Harry C. Moore Library \& Information Centre}

The vision of a new library persisted, and after several false starts and many years of planning, the dream was finally realized. ${ }^{2}$ Philanthropist, Harry C. Moore, a long-time resident of Lyford Cay, spearheaded a campaign to build a university library for the College of The Bahamas. In an age when some people believe "everything is on the internet, so why

\footnotetext{
${ }^{2}$ An initial design of a new library was proposed by Bahamian architect Jackson Burnside in 2002; however, the contract was terminated and Bahamian architect Leslie Johnson of Axion was contracted to design and oversee the building of the new library. Groundbreaking for the new library took place on April 21, 2005.
} 
do you need a library?" there was of course some resistance to the idea of building a new multi-million dollar library. Harry C. Moore faced the sceptics, consulting with experts from across the United States, including the Library of Congress and the University of Hawaii, and in 1998 took College donors, architects and administrators to visit several great libraries in the United States to show what could and should be done for the College of The Bahamas. They agreed that libraries are indeed still relevant in the internet age, that students need a place to study, that not all resources are digitized and are available only on paper, that a library is not only a place to hold books and journals but is also the heart of the university - a place to display art, hold exhibits, house historical documents, and promote and preserve Bahamian culture and heritage.

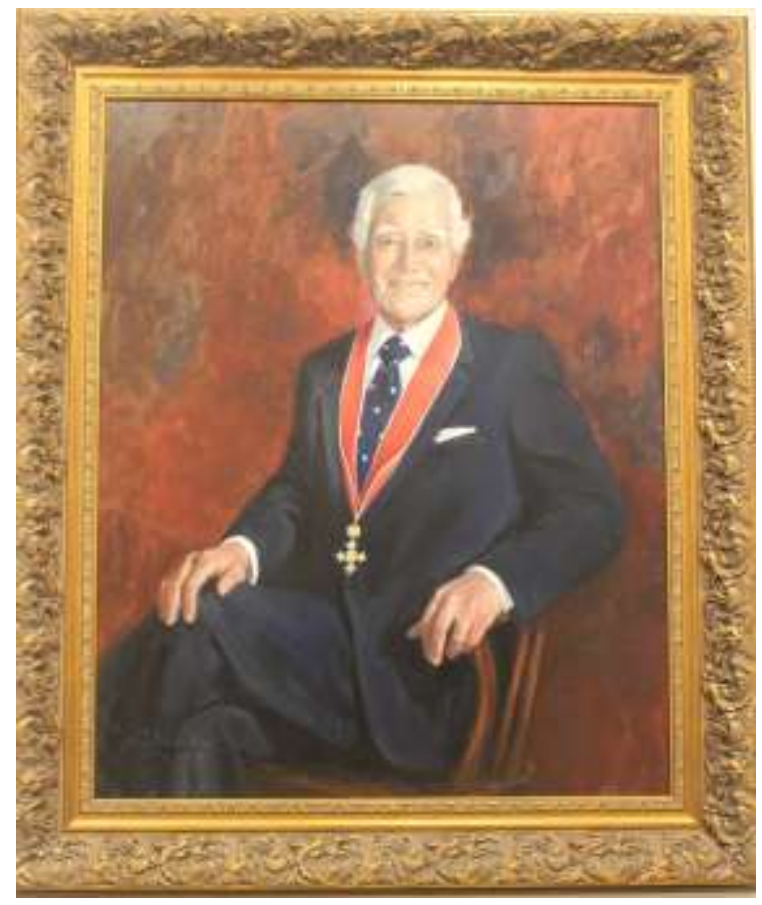

Figure 1. Portrait of Harry C. Moore, St., C.B.E.

In 2008 the Lyford Cay Foundation donated $\$ 5$ million toward a new library. Included in their vision was a virtual or digital library, a "library without walls" accessible on the internet, that would be accessible for all Bahamians; work on that project began immediately.

The College's new library, the Harry C. Moore Library and Information Centre was officially opened on April 8, 2011 by Prime Minister Hubert Ingraham. The 60,000 sq. ft. library, costing \$28 million, features a circular design around a three-storey atrium and can accommodate over 650 patrons. It is a spacious and attractive library, featuring a 24hour internet café, individual and group study rooms, bright seating areas, computer stations on all floors, a 114-seat auditorium as well as wireless internet access throughout the building. Two smaller library collections (the tourism and law libraries) located in The Bahamas Tourism Training Centre were moved to the new building and integrated into the collection.

The Harry C. Moore Library and Information Centre has eight professional librarians on staff heading all functional areas: Access Services, Reference, Technical Services, Acquisitions, Library Systems, Law Collection, and Special Collections as well as a full service Media and Audio-Visual Services department.

\section{Hilda Bowen Library}

In 1991, the programmes and campus of the Bahamas School of Nursing were transferred to the COB; this included the collection of the existing library. The library was initially called the Grosvenor Close Campus Library. However, on Florence Nightingale Day, May 12, 1994, it was renamed the Hilda Bowen Library, in honour of the first Bahamian Matron of the Princess Margaret Hospital. The health sciences library serves the School of Nursing and Allied Health Sciences and has a collection of approximately 4000 titles, 200 DVDs and medical models, and the Nursing History Archives and Rare Book Collection. The library is managed by a professional librarian and two library assistants.

Northern Campus Library (formerly known as the Freeport Centre Library) 
A library supporting the COB programmes offered in Freeport, Grand Bahama was established in September 1987 with a small collection of duplicate titles drawn from the Oakes Field Campus library (The Freeport Centre Library, 1988, p. 1). The library has grown and now holds over 7000 titles, inclusive of its Special Collections (Bull, 2014). Librarians Barbara Barton (19882006) and Christopher Bull (2007-) have moved the collection from a small reference/study room to a full-service library with a strong collection of Bahamian materials.

\section{COLLECTIONS Serials}

Included in the World Bank project of 1984 was the donation of over 800 academic journals on microfiche and microfilm as well as microfilm readers and a microfilm readerprinter (Rolle, 1985, p. 53). As digital technology evolved, the collection of microfilm was supplemented by a subscription to journals on CD-ROM from Proquest ${ }^{\mathrm{TM}}$. In 2000 the library moved to access online fulltext journals using EBSCO Information Services $^{\mathrm{TM}}$.

\section{Bahamian Special Collection}

The Bahamian Special Collection was established in 1980 to collect publications by Bahamians, about The Bahamas, or published in The Bahamas. In the absence of a national library, which normally would have this mandate, the Bahamian Special Collection has filled this role. The collection is located on the first floor of the Harry C. Moore Library and Information Centre and is closed access. Students and scholars must request materials via the librarian. In addition to monographs, the collection has an extensive assortment of Bahamian journals, government reports and newspaper clippings files. Included in the Special Collection room is the Caribbean Dissertations Collection, a compilation of more than 2000 dissertations written by
Caribbean scholars or about the Caribbean that was acquired in 1985, with considerable financial assistance from Syntex Chemicals and the Rotary Club. As well the West Indian Reference Collection is a major part of the collection.

\section{Hailey Collection}

The Arthur Hailey collection and exhibition is located on the ground floor of the Harry C. Moore Library and Information Centre in the Bahamian Special Collection room. This collection was acquired in 2012 and is a reconstruction of the award-winning author Hailey's study from his Lyford Cay home. This collection includes copies of all his published works (in many languages, and scripts), memorabilia, posters, pictures and photographs (Lundstrom, 2013). The Hailey family also made a generous donation to the College to assist with the upkeep of this exhibition.

\section{Bahamas Information Services Collection}

The Bahamas Information Services / The Counsellors public relations firm donated their extensive collection of video footage, audio cassettes, photographic negatives and still photographs to the College in 2013. This collection is housed in a room on the third floor of the Harry C. Moore Library and Information Centre and is under controlled access. The content is general in coverage.

\section{Pinding Collection and Exhibit}

The Lynden O. Pindling Room was opened in July of 2013. The collection is located in a large exhibition area on the second floor of the Harry C. Moore Library and Information Centre and includes photographs of the late Prime Minister's family life, his work desk, memorabilia about his life and times as the first Black Bahamian Prime Minister of the independent Commonwealth of The Bahamas. Significant items include several ball gowns worn by his wife, Marguerite, including the one worn at the Independence Ball held on 
July 10, 1973.

\section{College Archives}

The College of The Bahamas' Archives are located in the Harry C. Moore Library and Information Centre on the third floor in the Administration area. Here are housed many significant publications, photographs, reports and memorabilia relating to the College. Of late, documents relating to the work of the College's University Transition Secretariat have been added to the collection.

\section{Law Collection}

With the implementation of a Bachelor of Laws programme at the College in collaboration with the University of the West Indies, a small law library was established in 2000. Initially located in a separate facility, the law collection was moved into the Harry C. Moore Library and Information Centre in 2011 where it occupies a wing of the third floor.

\section{CHMI / SHTS Reading Room}

The College's hotel training programme (The Culinary and Hospitality Management Institute or CHMI, formerly known as the School of Hospitality and Tourism Studies) initially had a small reading room located in The Bahamas Tourism Training Centre. However, this collection was integrated into the Harry C. Moore Library and Information Centre collection in 2011.

\section{Oil Paintings}

In October 1993 the library acquired, in trust, a collection of oil paintings by Bahamian artists, which are on display in the Harry C. Moore Library and Information Centre. Among these are works by Antonious Roberts, David Smith, Max Taylor, and Amos Ferguson.

A large oil portrait of Harry C. Moore hangs in the foyer of the library (Figure 1).

A large oil painting Island Nurse: On Call by William McRae Gillies (1896-1976) is on display in the Hilda Bowen Library.

\section{Media Services}

A major part of the library's mission is to provide multimedia support at the College of The Bahamas. The Media Department has a wide array of educational technology: projectors, computers, video and audio recorders, and media software such as audio and video tapes, DVDs and slides as well as staff expertise to assist students and faculty. This department also administers the provision of laptops for teaching purposes. Plans are currently underway for the development of a student production centre within the media department.

\section{Library Education}

Basic education and continuing professional education for library workers and librarians has been an important part of the COB Library mandate. The first library education programmes began in 1982, building upon the Certificate programmes started at C. R. Walker Technical College in 1973-1975 and continued at COB from 1976 to the early 2000. COB also offered a Certificate, Diploma and Associate of Arts degree Programme (through the School of English Studies). As the demand for professional librarians grew in The Bahamas, the COB paired up with the University of South Florida in 2004 to offer a Masters of Library and Information Science degree to a cohort of 10 Bahamian students (USF SLIS, 2006, p. 1).

\section{Library Automation}

In 1994 the COB library implemented a computerized library system to automate processes, taking advantage of new technology, to build staff capacity and reduce redundancies in the workflow. The Datatrek $^{\mathrm{TM}}$ system was chosen as it could automate the acquisitions, cataloguing and circulation functions as well as provide an online catalogue. As technology improved, the Datatrek ${ }^{\mathrm{TM}}$ system's limitations became 
apparent and when its parent company announced that the product would no longer be supported after 2000, the library began looking for a new system (Walker, 2000).

The key feature for the replacement system was that should it be designed for an academic library. Exlibris's Voyáger system was chosen. It is used by many universities and research libraries (including the Library of Congress) and it had all the features and an interface that librarians and users wanted. As well, it was a web-based system so all branch libraries of the College could also use the same integrated system.

The online catalogue, called COBWEB, is available on the web at this link: http://bahamas-voyager-

linux.hosted.exlibrisgroup.com/

\section{Library Programmes}

For many years LIMS held an annual LIMS Week. One memorable week held in 2003 was themed Uncovering the Mysteries, for which the library won a Gale Award for promoting innovative and effective information services using information technologies. (LIMS award, 2003, p. 1).

A popular library programme initiated in the mid-1990s was Meet the Writer. Bahamian poets and authors of both fiction and nonfiction works were invited to speak and present their work. The programme evolved to become a collaboration between the library, the School of English Studies and COB's ChapterOne Bookstore. It is held annually to support local authors and publishers.

In January of 2007, the Law Library staff began a programme called Lunch and Litigation, which was later changed to Lunch and the Law to better reflect the topics presented. The first event was held at the CHMI Choices Restaurant with the Hon. Allison Maynard-Gibson, Attorney General and Minister of Legal Affairs speaking about the 2006 Consumer Protection Act. Other events were held at the British Colonial Hilton Hotel where prominent Bahamian legal personalities, such as former Chief Justice Sir Burton Hall, were the featured speakers.

The Library Informer newsletter was for nearly 20 years, the Library's method of communicating with its patrons. (All copies of the Library Informer may be found on the Digital Library of the Caribbean website at http://www.dloc.com/icobn). In the 21st century, however, the Library's webpage, Facebook account, Twitter feed and blog have supplanted the printed newsletter.

LIMS has taken the lead in providing continuing education for librarians in The Bahamas by holding day-long symposia. The first LIMS Symposium was held in 2007 and has been held every other year. Additionally, COB librarians have participated in the Association of Caribbean Universities and Research Institute Libraries (ACURIL) conferences when they were held in The Bahamas, in 2000 and 2014 and to a limited extent, when held in other Caribbean countries and North America.

\section{Oral History}

A 1983 report on the future direction of the library urged that an "oral history unit should begin as soon as possible" (Dunathan, 1983, p. 14). The Oral History Initiative got started January 1990 recording memoirs and collecting photographs for "Remembering the Contract", in commemoration of the 50th anniversary of a bilateral farm labour programme between the governments of the United States and The Bahamas (From the Librarian's desk, 1993, p. 1; see also Thompson, 2013). After a hiatus of 20 years, the oral history programme was reinitiated as From Dat Time: Oral and Public History Institute, with the mandate to collect oral histories and photographs and to produce scholarly articles, exhibitions and documentary videos. 


\section{The American Corner}

In June 2013, the U.S. State Department's Director of Caribbean Affairs, Juan Alsace and the United States Embassy's Chargé d'Affairs, John Dinkleman met with COB President Dr. Betsy Vogel-Boze to announce the establishment of an American Corner on the first floor of the Harry C. Moore Library. Included was a grant of $\$ 23,000.00$ from the United States government to purchase multimedia equipment and printed resources.

\section{Future directions}

As the College looks toward the future, the role of the library has expanded from its traditional role as a storehouse of books and journals to become a dynamic creator of scholarly content. There are active projects digitizing Bahamian historical documents and making them freely available online through the Digital Library of the Caribbean, thereby creating a digital repository. The library also promotes scholarly communications through publications such as the International Journal of Bahamian Studies. Librarians are engaged in teaching students and faculty how to locate, use, and present scholarly research.

\section{REFERENCES}

Ballance, V., \& Bain, E. (2000). Bahamian public libraries: An overview. Nassau, Bahamas: Bahamas Library Publications. Available at http://ufdc.ufl.edu/AA00007599/00001

Boultbee, P. (1981). Bahamian reference collection: Bibliography. (2nd ed.). Nassau, Bahamas: The College of The Bahamas Library.

Boultbee, P. (1989). The Bahamas. Santa Barbara, CA: ABC-Clio.

Bull, C. (2014). Northern Bahamas Library, 2013-14 annual report. (Unpublished).

Dunathan, A. (1983). Plan for the development of the College of The Bahamas library, 1982-1986. (typescript).

Freeport Centre Library. (1988, March). Library Informer, 1(5), 1. Available at http://ufdc.ufl.edu/AA00024198/00001

From the Librarian's desk. (1993, September/October). Library Informer, 5(8/9), 1. Available at http://ufdc.ufl.edu/AA00008979/00001

LIMS award. (2003, Fall). Library Informer, 13(2), 1. Available at http://ufdc.ufl.edu/AA00024147/00001
Lundstrom, T. E. (2013). The Arthur Hailey collection. The International Journal of Bahamian Studies, 19, 1-2. http://dx.doi.org/10.15362/ijbs.v19i1.183

Rolle, V. (1985). The library. In College of the Bahamas tenth anniversary, 19751985. (pp. 53-54). Nassau, Bahamas: The College of The Bahamas.

Thompson, T. L. (2012). Remembering "The Contract": Recollections of Bahamians. The International Journal of Bahamian Studies, 18, 6-12. http://dx.doi.org/10.15362/ijbs.v18i0.169

USF SLIS enters partnership with College of the Bahamas. (2006). The Link, 1(2), 1.

Retrieved from http://si.usf.edu/communication/link/USFSLIS-thelink-v1i2.pdf

Walker, B. L. (2000). Casting into the deep: A history of library technology in The Bahamas. Computers in Libraries, 20(10), 48-54. 